\title{
Comparison of immunofluorescence and culture for the detection of Actinomyces israelii in wearers of intra-uterine contraceptive devices
}

\author{
D. E. LESLIE* and SUZANNE M. GARLAND† \\ Microbiology Department, The Royal Women's Hospital, Melbourne, Australia
}

\begin{abstract}
Summary. A direct immunofluorescence (IF) method was compared with traditional culture methods for the detection of Actinomyces israelii in endocervical and intra-uterine-device (IUD) smears from 124 IUD wearers. Of 11 specimens that gave positive results by IF, only one was positive by culture. Of the 10 patients with positive IF specimens, three $(30 \%)$ had signs and symptoms suggestive of pelvic infection and no other pathogen was detected. Direct IF of cervical smears offers a simple, relatively cheap method to screen IUD wearers for $\boldsymbol{A}$. israelii. Clinical management of such cases is discussed.
\end{abstract}

\section{Introduction}

In the past 20 years, over 400 cases of pelvic actinomycosis have been reported throughout the world, predominantly in association with the wearing of an intra-uterine contraceptive device (IUD). ${ }^{1}$ Genital actinomycosis is a non-contagious, chronic, suppurative disease which leads to fibrosis and may present as a "frozen pelvis", tubo-ovarian abscess, or with uterine and endometrial involvement. The principal pathogen, Actinomyces israelii, is a fastidious, slowly growing, filamentous, gram-positive anaerobe. Consequently, diagnosis by traditional culture methods from genital swabs is slow, tedious and relatively insensitive. Immunofluorescence (IF) with direct smears of the genital tract provides a rapid method for the identification of $A$. israelii by morphological and immunological characteristics. ${ }^{1}$ We report the use of an IF stain of smears, from the endocervices of IUD wearers and from IUDs at removal, in the Royal Women's Hospital, Melbourne, over a 4-month period and discuss the clinical significance and management of patients with a positive smear.

\section{Materials and methods}

\section{Patients}

The study group consisted of 124 women with an IUD in situ who attended the Family Planning Clinic (FPC), Gynaecology Clinic or Emergency Department

Received 4 Oct. 1990; revised version accepted 22 Jan. 1991.

* Present address: Fairfield Hospital, Victoria, Australia.

† Correspondence should be sent to: Dr S. Garland, Microbiology Department, Royal Women's Hospital, 132 Grattan Street, Carlton 3053, Victoria, Australia. of the Royal Women's Hospital, Melbourne, between Sept. 1988 and Jan. 1989. IUDs included plastic devices such as Lippes Loops and copper-containing devices. The reasons for presentation were: attendance for cessation of contraception, for change of IUD (recommended at the FPC for all copper IUDs after 2 years, or earlier if symptoms occur), for symptoms or signs suggestive of pelvic infection (such as lower abdominal pain, vaginal discharge, altered menses; and lower abdominal or cervical or adnexal tenderness on examination), or for clinical review after previous episodes of infection or,abnormal test results, e.g., cervical cytology reports of the presence of actinomyces-like organisms.

\section{Specimens}

The attending medical practitioner placed a cottontipped swab in the endocervix of each patient who presented at the Hospital, and smeared the swab on to two glass slides for staining by Gram's method and IF. Horse-blood agar (HBA) was inoculated with a second endocervical swab, which was then placed into cooked-meat broth; two further swabs, one of them a charcoal swab, were placed into Amies transport medium.

It has been Hospital policy that, before IUD insertion, all patients are screened for Chlamydia trachomatis by wiping away any remaining pus or mucus with a cotton swab, then sampling the endocervix with a cotton-tipped aluminium ENT swab (Medical Wire and Equipment Co., Wilts). Swabs were placed in a sucrose phosphate glutamate transport medium ${ }^{2}$ supplemented with vancomycin $10 \mu \mathrm{g} /$ $\mathrm{ml}$, gentamicin $20 \mu \mathrm{g} / \mathrm{ml}$, and amphotericin B $10 \mu \mathrm{g} /$ $\mathrm{ml}$; they were transported to the laboratory on ice, 
and were either processed the same day or stored at $-70^{\circ} \mathrm{C}$

After removal, IUDs were placed in sterile containers and sent to the laboratory immediately. On arrival, a smear from the IUD was made on a glass slide, for IF staining; it was heat-fixed and stored until tested near the end of the study period.

\section{Bacteriology}

One of the cervical smears was stained by Gram's method and examined for polymorphs and organisms. The HBA that had been inoculated with a cervical swab was incubated at $37^{\circ} \mathrm{C}$ in $\mathrm{CO}_{2} 5-10 \%$ for $24 \mathrm{~h}$; and the cooked-meat broth was incubated at $37^{\circ} \mathrm{C}$ for $24 \mathrm{~h}$ before routine subculture for anaerobes. Actinomyces agar $^{3}$ (modified by the addition of metronidazole $5 \mu \mathrm{g} / \mathrm{ml}$ ) was inoculated with the plain cotton swab from Amies medium, and incubated anaerobically at $37^{\circ} \mathrm{C}$ for 4 weeks; plates were examined weekly, and the identity of likely colonies was confirmed by gram-stain morphology and by gasliquid chromatography. Thayer-Martin medium was inoculated with the charcoal swab in Amies medium for the detection of Neisseria gonorrhoeae.

Swabs from the IUDs were inoculated on to HBA $\left(37^{\circ} \mathrm{C}, \mathrm{CO}_{2} 5-10 \%, 24 \mathrm{~h}\right)$, on to supplemented HBA for anaerobic organisms ${ }^{4}\left(37^{\circ} \mathrm{C}\right.$, anaerobically, $\left.48 \mathrm{~h}\right)$ and on to actinomyces agar $\left(37^{\circ} \mathrm{C}\right.$, anaerobically, 4 weeks). Bacteria were identified by conventional bacteriological methods $;^{5}$ they included potential pathogens such as Staphylococcus aureus, coliforms, $\beta$ haemolytic streptococci, large numbers of anaerobes and actinomyces. Specimens for $C$. trachomatis were cultured on HeLa-229 cells in 48 -well cluster trays as described previously. ${ }^{6}$

\section{Immunofluorescence}

The method of Pine et al. ${ }^{7}$ was used with minor modifications. Briefly, heat-fixed smears were digested with pepsin solution (140 U/ml in $0.01 \mathrm{~N} \mathrm{HCl}$; Sigma) for $3 \mathrm{~h}$; they were then rinsed and dried, and $20 \mu \mathrm{l}$ of fluorescein-conjugated antibody to $A$. israelii types I and II (Biological Products Division, Centers for Disease Control, Atlanta, GA, USA) was spread over an area $1-\mathrm{cm}$ square. After incubation at $37^{\circ} \mathrm{C}$ for 20 min, the slides were thoroughly rinsed, and were counterstained with aqueous Evans Blue $0.5 \%$ for 2 min. They were then rinsed, dried, and mounted in phosphate-buffered saline with glycerol, and examined by fluorescence microscopy (Leitz) with 450-490-nm excitor and 515-nm suppressor filters.

A control slide, with each IF test, consisted of a negative smear containing cellular material, normal vaginal bacterial flora, and mucus from an actinomyces-free IUD, and positive smears made by mixing material from the same negative IUD with $A$. israelii type 1 (ATCC 12103) and type 2 (ATCC 19322) grown in Brewer's thioglycollate medium. Smears of orga- nisms found in the normal vagina (diphtheroids, lactobacilli, streptococci and coliforms), and of Arachnia propionica, were also tested.

IF was graded subjectively from 0 (no detectable cell wall IF) to 4 (the intense fluorescence of the positive control).

\section{Identification criteria}

Slides were considered to be positive for $A$. israelii if examination revealed more than two microcolonies of filamentous bacteria with evidence of branching and strong IF of the cell wall (grade 3-4). Older positive specimens tended to have a more granular appearance. In most cases, actinomyces microcolonies were embedded in faintly staining amorphous cellular debris, often with large numbers of leucocytes in the smear. Inadequate slides, with no visible cellular material before digestion, were rejected.

\section{Cytology}

All patients reviewed at the Hospital clinics were screened for dysplasia or neoplasia, by cervical cytology. Ecto- and endo-cervices were sampled by Ayre spatulae and cytobrushes respectively; smears were made and fixed immediately, and stained by the method of Papanicolaou.

\section{Results}

\section{Specificity of the IF test}

No more than a trace of fluorescence (less than grade 1) was observed in smears of vaginal commensal bacteria. Occasionally, fungal hyphae showed weak fluorescence (grade 1-2), but these were readily distinguished from actinomyces by size and other morphological features. Despite previously reported low-level antigenic cross-reactions, ${ }^{1,7}$ a smear of the actinomyces-like organism, Ar. propionica, did not even show grade 1-2 fluorescence.

\section{Detection of actinomyces}

A total of 131 specimens (82 cervical and 49 IUD) from 124 patients was examined. Nine $(11 \%)$ of the cervical smears and two (4\%) of the IUD smears were positive by IF for $\boldsymbol{A}$. israelii (table I); these specimens were from 10 patients. Only one specimen was positive by culture, a cervical swab from a patient with an IUD in situ for 18 months, who complained of lower abdominal pain and vaginal discharge; this patient's cervical smear was also positive by IF. The IUD was removed from three of the 10 patients with a positive cervical smear; in only two of these three was the IUD smear positive by IF. 
Table I. Results of specimens tested for $A$. israelii over a period of 4 months from Sept. 1988 to Jan. 1989

\begin{tabular}{lc|cccc}
\hline \multirow{2}{*}{ Specimen } & Number tested & \multicolumn{4}{|c}{ Number $(\%)$ positive by } \\
\cline { 3 - 6 } & & \multicolumn{2}{|c}{ IF } & \multicolumn{2}{c}{ culture } \\
\hline Cervical smear & 82 & 9 & $(11)$ & 1 & $(1)$ \\
IUD smear & 49 & $2 \dagger$ & $(4)$ & 0 & \\
Total & $131^{*}$ & 11 & $(8)$ & 1 & $(0 \cdot 7)$ \\
\hline
\end{tabular}

* Both cervical smears and IUDs were received from seven patients.

$\uparrow$ The two positive IUDs were from patients with positive cervical smears, though one of the cervical specimens was received outside the 4-month study period.

\section{Symptoms and management of patients}

Details of the 10 patients positive for $A$. israelii are outlined in table II. IUDs in all these patients had been present for at least 13 months (mean, 29 months). Clinically, three were asymptomatic; two had minor complaints (discharge with or without lower abdominal pain); three had symptoms and signs suggestive of pelvic inflammation, not in association with other recognised pathogens; two had other pathogens also (chlamydia or trichomonas). In the patient with chlamydia, symptoms were sufficiently severe to require admission to hospital for treatment of pelvic inflammatory disease (PID). Of the asymptomatic patients, two presented for cessation of contraception; the third (no. 9) came for a routine IUD change, but because of the presence of actinomyces the IUD was removed and an oral contraceptive was prescribed; all three were managed by IUD removal alone. Those with pelvic signs were managed with antibiotics

Table II. Ten patients in whose specimens $A$. israelii was detected by immunofluorescence (IF)

\begin{tabular}{|c|c|c|c|c|c|c|c|c|}
\hline \multirow{2}{*}{$\begin{array}{c}\text { Patient } \\
\text { no. }\end{array}$} & \multirow{2}{*}{$\begin{array}{c}\text { Age } \\
\text { (years) }\end{array}$} & \multirow{2}{*}{$\begin{array}{l}\text { Duration } \\
\text { of IUD use } \\
\text { (months) }\end{array}$} & \multirow{2}{*}{$\begin{array}{l}\text { Reason for } \\
\text { attendance }\end{array}$} & \multicolumn{2}{|c|}{$\begin{array}{l}\text { IF result with } \\
\text { smear from }\end{array}$} & \multirow{2}{*}{$\begin{array}{c}\text { Result of } \\
\text { culture } \\
\text { for } A . \text { israelii }\end{array}$} & \multirow{2}{*}{$\begin{array}{l}\text { Symptoms, signs and } \\
\text { other pathogens }\end{array}$} & \multirow{2}{*}{ Management } \\
\hline & & & & cervix & IUD & & & \\
\hline 1 & 22 & 18 & Unwell & + & ND & + & $\begin{array}{l}\text { LAP } \\
\text { PV-discharge }\end{array}$ & $\begin{array}{l}\text { IUD-removal } \\
\text { metronidazole } \\
\text { doxycycline } \\
\text { IUD-replacement }\end{array}$ \\
\hline 2 & 22 & 20 & Unwell & + & ND & - & $\begin{array}{l}\text { LAP } \\
\text { PV-discharge } \\
\text { fever } \\
\text { PID } \\
\text { Chlamydia }\end{array}$ & $\begin{array}{l}\text { IUD-removal } \\
\text { metronidazole } \\
\text { doxycycline }\end{array}$ \\
\hline 3 & 35 & 58 & $\begin{array}{l}\text { Cessation of } \\
\text { contraception }\end{array}$ & $+^{*}$ & + & - & None & IUD-removal \\
\hline 4 & 29 & 17 & Unwell & + & ND & - & $\begin{array}{l}\text { LAP } \\
\text { PV-discharge } \\
\text { Cx-excitation }\end{array}$ & $\begin{array}{l}\text { Amoxycillin } \\
\text { metronidazole } \\
\text { IUD-removal }\end{array}$ \\
\hline 5 & 40 & 36 & Unwell & + & ND & - & $\begin{array}{l}\text { LAP } \\
\text { PV-discharge } \\
\text { Cx-excitation }\end{array}$ & $\begin{array}{l}\text { Amoxycillin } \\
\text { metronidazole } \\
\text { IUD-removal } \\
\text { IUD-replacement }\end{array}$ \\
\hline 6 & 20 & 24 & Unwell & + & + & - & $\begin{array}{l}\text { LAP } \\
\text { PV-discharge } \\
\text { Cx-excitation }\end{array}$ & $\begin{array}{l}\text { IUD-removal } \\
\text { amoxycillin } \\
\text { metronidazole }\end{array}$ \\
\hline 7 & 28 & 25 & Unwell & + & - & - & $\begin{array}{l}\text { LAP } \\
\text { PV-discharge } \\
\text { Trichomonas }\end{array}$ & $\begin{array}{l}\text { IUD-removal } \\
\text { metronidazole }\end{array}$ \\
\hline 8 & 25 & 13 & $\begin{array}{l}\text { Cessation of } \\
\text { contraception }\end{array}$ & + & - & - & None & IUD-removal \\
\hline 9 & 36 & 36 & $\begin{array}{l}\text { Routine change } \\
\text { of IUD }\end{array}$ & + & ND & - & None & IUD-removal \\
\hline 10 & 26 & 42 & Unwell & + & ND & - & PV-discharge & IUD-removal \\
\hline
\end{tabular}

ND, not done during the study period; LAP, lower abdominal pain; PV, per vaginam; PID, pelvic inflammatory disease; Cx, cervix. * This specimen was collected outside the study period. 
(usually amoxycillin and metronidazole, or metronidazole and doxycycline) and removal of the IUD. In two cases (nos. 4 and 5), antibiotics alone were used initially; however, symptoms persisted until the IUD was removed. No patient had invasive actinomycosis requiring surgical intervention.

Ecto- and endo-cervical smears for cytology, taken from seven patients at the same time as cervical smears were taken for actinomyces detection, revealed branching organisms in three $(43 \%)$, thus predicting the possible presence of actinomyces. Routine microbiological examination of cervical swabs of the 10 positive cases revealed mixed anaerobic organisms, Gardnerella vaginalis, Streptococcus milleri, Str. agalactiae, Haemophilus sp., Escherichia coli and Candida albicans. C. trachomatis also was isolated from one patient (see above).

\section{Discussion}

The incidence of PID is reported to be higher in IUD users than in non-users, ${ }^{8}$ although the type of IUD, patient selection, and the presence of sexually transmitted organisms are important factors in assessing the real risk. $^{9-11}$ In most instances PID is polymicrobial, with various aerobes and anaerobes in addition to sexually transmitted organisms, the commonest of which is C. trachomatis. $^{12}$ Reports of Actinomyces spp. in cases of PID in IUD wearers have varied from $17 \%$ to $25 \%{ }^{13,14}$ the most significant risk factor for genital actinomycosis has been long-term usage of an IUD. ${ }^{15,16}$

The method of choice for the detection of $A$. israelii in genital specimens ${ }^{1,14,17,18}$ has been IF. Culture techniques are insensitive because of the oxygensensitive, fastidious and slow-growing nature of the organisms, and difficulty in selecting it from other faster-growing anaerobes ${ }^{18-20}$ found in the normal flora of the genital tract. This has been demonstrated in our study, in which only one patient was positive by culture. Examination of Papanicolaou-stained smears for the presence of actinomyces-like organisms has been shown to be more sensitive than culture, but it still lacks sensitivity and specificity even in the most highly skilled hands. ${ }^{16,17}$ Furthermore, by morphology alone, it is not possible to distinguish $A$. israelii from related Actinomyces, Arachnia and Nocardia. In contrast, IF can utilise both morphology and antigenic features. The anti- $\boldsymbol{A}$. israelii conjugate used in this study, and other similar preparations, have been tested extensively by several authors ${ }^{7,16,18}$ who found this to be the most sensitive and specific method for the detection of $A$. israelii. Also, this method can be applied directly to histological sections in cases of invasive disease. ${ }^{7}$

Actinomyces is detected frequently in genital smears of asymptomatic IUD wearers. The clinical significance is uncertain, and whether this represents a risk factor for subsequent development of PID is a pertinent question. Where IF has been used in both retrospective and prospective studies, there are two schools of thought. One believes that recognition of actinomyces in a genital smear is always related to a foreign body, most commonly an IUD. ${ }^{13,16}$ Although in the majority of such patients infection is confined to the superficial layers of the endometrium, there is potential for more serious disease if the device remains in situ. In contrast, others ${ }^{1,7,21,22}$ consider actinomyces colonisation in healthy non-IUD users to be part of the normal indigenous vaginal flora. Generally, colonisation rates reported by the latter group were low but the study populations were small (table III). In our 4-month study, nine (11\%) of 82 cervical smears from IUD users were positive for actinomyces; the rate for the whole of 1989 was $10 \%$, of 350 specimens. Three $(30 \%)$ of our positive patients had significant symptoms, a higher proportion than expected; and three $(30 \%)$ were asymptomatic. In all seven symptomatic patients, the IUD had been in situ for more than 13 months (mean, 29 months).

With such diversity of opinion, the management of IUD users with actinomyces is somewhat arbitrary, and varies from centre to centre. ${ }^{1,7,13,14,21,22}$ For

Table III. Comparison of present results with previous studies of $\boldsymbol{A}$. israelii immunofluorescence (IF) in smears from patients with and without an IUD

\begin{tabular}{|c|c|c|c|c|}
\hline \multirow[b]{2}{*}{ Study } & \multicolumn{2}{|c|}{ Patients with IUD } & \multicolumn{2}{|c|}{ Patients without IUD } \\
\hline & $\begin{array}{c}\text { Number } \\
\text { of } \\
\text { patients }\end{array}$ & $\begin{array}{c}\text { Number } \\
(\%) \\
\text { IF-positive }\end{array}$ & $\begin{array}{c}\text { Number } \\
\text { of } \\
\text { patients }\end{array}$ & $\begin{array}{c}\text { Number } \\
(\%) \\
\text { IF-positive }\end{array}$ \\
\hline 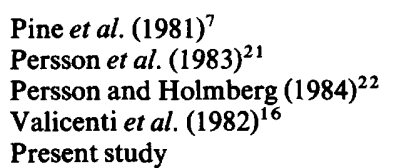 & $\begin{array}{r}18 \\
68 \\
5 \\
6450 \\
82\end{array}$ & $\begin{array}{c}7(39) \\
3(4) \\
5(100)^{*} \\
103(2) \dagger \\
9(11)\end{array}$ & $\begin{array}{r}32 \\
68 \\
10 \\
63250 \\
0\end{array}$ & $\begin{array}{c}4(12) \\
2(3) \\
10(100)^{*} \\
\mathrm{ND} \dagger\end{array}$ \\
\hline
\end{tabular}

ND, not done.

* Multiple genital and perineal sites from each patient were cultured over two menstrual cycles.

† Papanicolaou-stained smears were examined for actinomyces-like organisms. These were not detected in 63250 smears from women without IUDs; but they were found in 212 of 6450 smears from IUD wearers and, when these 212 were re-examined by IF, 103 were positive. 
IUD wearers, we propose that $A$. israelii be sought by IF of a cervical smear at 2-year intervals, or earlier if symptoms occur. An asymptomatic IUD user with actinomyces should have the device removed, and should use other means of contraception. Alternatively, after 2-3 months, another cervical smear may be examined; if negative for $\boldsymbol{A}$. israelii, as is usual in our experience, another IUD may be inserted.

If the IUD wearer presents with localised symptoms, we recommend antibiotic therapy (amoxycillin and metronidazole, or doxycycline, for 2-3 weeks) and removal of the IUD. Fortunately pelvic actinomycosis is uncommon; but it is a serious and potentially lifethreatening infection. If a pelvic mass is evident,

\section{References}

1. Persson E. Genital actinomycosis and Actinomyces israelii in the female genital tract. Adv Contracept $1987 ; 3: 115-123$.

2. Bovarnick MR, Miller JC, Snyder JC. The influence of certain salts, amino acids, sugars, and proteins on the stability of rickettsiae. J Bacteriol 1950; 59: 509-522.

3. Pine L, Watson SJ. Evaluation of an isolation and maintenance medium for actinomyces species and related organisms. $J$ Lab Clin Med 1959; 54: 107-114.

4. Lennette EH, Balows A, Hausler WJ, Shadomy HJ. Manual of clinical microbiology, 4th edn. Washington, DC, American Society for Microbiology. 1985.

5. Cowan ST. Cowan and Steel's Manual for the identification of medical bacteria, 2nd edn. Cambridge, Cambridge University Press. 1977.

6. Lees MI, Newnan DM, Garland SM. Simplified culture procedure for large-scale screening for Chlamydia trachomatis infections. J Clin Microbiol 1988; 26: 1428-1430.

7. Pine L, Malcom GB, Curtis EM, Brown JM. Demonstration of Actinomyces and Arachnia species in cervicovaginal smears by direct staining with species-specific fluorescent-antibody conjugate. J Clin Microbiol 1981; 13: 15-21.

8. Weström L. Incidence, prevalence, and trends of acute pelvic inflammatory disease and its consequences in industrialized countries. Am J Obstet Gynecol 1980; 138: 880-892.

9. Kessel E. Pelvic inflammatory disease with intrauterine device use : a reassessment. Fertil Steril 1989; 51:1-11.

10. Edelman DA. IUD complications in perspective. Contraception $1987 ; 36: 159-167$

11. Daling JR, Weiss NS, Metch BJ et al. Primary tubal infertility in relation to the use of an intrauterine device. $N$ Engl $J$ Med 1985; 312: 937-941.

12. Venezio FR, O'Keefe JP. Microbiologic considerations in the aggressive and prolonged antibiotic therapy with possible surgical intervention is required. In 6 years at the Royal Women's Hospital, one of us (SMG) has found records of only two cases of tubo-ovarian abscess due to actinomycosis; both were associated with IUD usage, and both presented with pelvic fibrosis, ovarian carcinoma being the provisional diagnosis until histology of frozen sections suggested actinomycosis.

We thank Dr Gytha Betheras, FPC, Royal Women's Hospital, for helpful discussion of this manuscript and Mrs Judy Jackson for typing it.

Addendum. Actinomyces antisera are no longer available from the Centers for Disease Control, Atlanta, GA, in the large quantities that may be needed for routine diagnostic use.

treatment of serious pelvic infections in women. $J$ Reprod Med 1988; 33: 124-127.

13. Burkman R, Schlesselman S, McCaffney L, Gupta PK, Spence $M$. The relationship of genital tract actinomycetes and the development of pelvic inflammatory disease. Am J Obstet Gynecol 1982; 143: 585-589.

14. Gupta PK, Woodruff JD. Actinomyces in vaginal smears. JAMA 1982; 247: 1175-1176.

15. Duguid HLD, Parratt D, Traynor R. Actinomyces-like organisms in cervical smears from women using intrauterine contraceptive devices. $\mathrm{Br} \mathrm{Med} \mathrm{J} \mathrm{1980;} \mathrm{281} \mathrm{:} \mathrm{534-537.}$

16. Valicenti JF, Pappas AA, Graber CD, Williamson HO, Willis NF. Detection and prevalence of IUD-associated Actinomyces colonization and related morbidity. JAMA 1982; 247: 1149-1152.

17. Pine L, Curtis EM, Brown JM. Actinomyces and the intrauterine contraceptive devices: aspects of the fluorescent antibody stain. Am J Obstet Gynecol 1985; 152 : 287-290.

18. Gerencser MA. The application of fluorescent antibody techniques to the identification of Actinomyces and Arachnia. In: Bergan T, Norris J R (eds) Methods in Microbiology No. 13. London, Academic Press. 1979: 287-321.

19. Jarvis D. Isolation and identification of actinomycetes from women using intrauterine contraceptive devices. $J$ Infect 1985; 10: 121-125.

20. Traynor RM, Parratt D, Duguid HLD, Duncan ID. Isolation of actinomycetes from cervical specimens. J Clin Pathol $1981 ; 34$ : 914-916.

21. Persson E, Holmberg K, Dahlgren S, Nilsson L. Actinomyces israelii in the genital tract of women with and without intra-uterine contraceptive devices. Acta Obstet Gynecol Scand 1983; 62: 563-568.

22. Persson E, Holmberg K. A longitudinal study of Actinomyces israelii in the female genital tract. Acta Obstet Gynecol Scand 1984; 63: 207-216. 